PAW HEDEGAARD AMDISEN

\section{Giganternes kamp}

Ole Morsing: Logstrup \& Sløk, Løgstrup Biblioteket, Klim, 2011, 142 sider, $199 \mathrm{kr}$.

Der er næppe megen tvivl om, at teologien har spillet og stadig spiller en fremtrædende rolle i den intellektuelle debat herhjemme. Hovedpersonerne i den bog, der her skal anmeldes, er gode eksempler fra en ikke så fjern fortid på, at danske teologer har været med til at sætte deres samtids intellektuelle diskussion. Jeg tænker på K. E. Løgstrup og Johannes Sløk, hvis indbyrdes teologiske og filosofiske kampe danner udgangspunkt for Ole Morsings idéhistoriske portræt i bogen Løgstrup \& Sløk, der i det sene forår 2011 udkom i forlaget Klims udgivelsesrække Løgstrup Biblioteket.

Det er værd at slå fast med det samme, at der er tale om god lille bog, der i ti tematiske afsnit sætter Sløks og Løgstrups respektive forfatterskaber i tæt relation til hinanden, men samtidig også får portrætteret polemikken mellem de to, som den væsentlige filosofisk-teologiske diskussion, den i virkeligheden var og er. Bogens store styrke er, at den tegner billedet af en intellektuel kamp mellem to meget jævnbyrdige tænkere, der måske delte udgangspunkt i en eksistensfilosofisk tolkning af teologien, men også allerede fra starten af deres respektive intellektuelle løbebaner havde meget forskellige indgange til tilværelsen og menneskets grundvilkår. På den måde overskrides den vanlige fremstilling af Løgstrup som den filosofisk set dybe tænker og Sløk som den letbenede populist, der havde mere travlt med selvpromovering og avisskriverier, end med at producere det store filosofiske hovedværk, der eksempelvis kunne matche Løgstrups Metafysik-bøger.

Ole Morsing får således gjort det tydeligt, hvordan de intellektuelle uenigheder mellem Løgstrup og Sløk ikke "bare" bunder i forskellige Kierkegaard-opfattelser, men også i helt grundlæggende uenigheder omkring tolkningen af menneskets position i forhold til omverden og Gud. Løgstrups nærmest ubegrænsede tillid og ukuelige optimisme overfor Sløks absurdistiske pessimisme. Løgstrups skabelses- eller skabthedsteologi overfor Sløks særegne blanding af eksistentiel og narrativ teologi, der også, som Morsing fremhæver det, kan ses som en form 
for åbenbaringsteologi.

Bogen er som antydet iscenesat som en række tematiske kampe, hvor de to - vel ikke mindst i deres selvopfattelse - teologiske giganter spilles ud i forhold til hinanden på en måde, så man nærmest har fornemmelsen af, at de lige nu og her kunne sidde overfor hinanden i et tryllebundet auditorium og udveksle vigtige filosofisk-teologiske pointer og gensidige giftigheder. Denne form, hvor Løgstrups og Sløks forfatterskaber og tænkning præsenteres og fortolkes i gensidig og ikke mindst ligeværdig dialog med hinanden gør bogen levende, men styrker samlet set også forståelsen af de to respektive forfatterskaber.

Politikens anmelder Lars Sandbeck begræder i sin anmeldelse af bogen, at Ole Morsing ikke harmoniserer "Løgstrups og Sløks tænkning", tager "parti for en af parterne" og " konsekvent undlader at diskutere, vurdere og kritisere", hvorved hele øvelsen bliver "udialektisk". Jeg må erklære mig helt uenig. Ved netop at fremstille Løgstrups og Sløks tænkning som langt hen af vejen inkommensurable størrelser får vi nemlig en sand dialektik - valgets dialektik - på banen. Løgstrups og Sløks tænkning er to forskellige bud på nogle af livets store spørgsmål. Begge bud er på egne betingelser gyldige, så vi er i bund og grund overladt til valget og afgørelsen, og dér efterlader Morsing os så på god dialektisk manér.

Det er ikke første gang, at Ole Morsing tager livtag med Løgstrups og Sløks indbyrdes forhold, men den lidt længere bogform, hvor der er plads til den føromtalte iscenesættelse virker som den helt rigtige platform. Bogen kan varmt anbefales som appetitvækker og indgangsvinkel til de to teologiske giganter og deres tænkning og forfatterskab, og som man har kunnet notere sig, så har interessen for bogen allerede været stor, hvilket kunne tyde på, at vi også har at gøre med en bog, der helt i både Løgstrups og Sløks ånd kunne risikere at få et liv uden for universitetsverdenens mure.

LARS ERSLEV ANDERSEN

\section{Illusioner om ikke-vold}

Mikkel Thorup: An Intellectual History of Terror. War, violence and the state, Routledge Critical Terrorism Studies, London, 2010, 282 sider.

Idehistoriken Mikkel Thorup har skrevet en vigtig, relevant og lærd bog om den politiske volds idehistorie. Der er al mulig god grund til at håbe og opfordre til, at denne bog opnår stor udbredelse og at den også læses af andre end forskere, navnlig beslutningstagere, der er optaget af 